\title{
Review of the wood anatomy of extant Ulmaceae as context for new reports of late Eocene Ulmus woods
}

\author{
Elisabeth A. Wheeler \& SteVen R. MAnChester
}

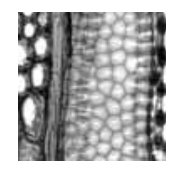

\begin{abstract}
Wood anatomy of extant Ulmaceae is briefly reviewed to provide context for descriptions of corresponding fossil woods, with attention to newly recognized woods from the late Eocene of Oregon, USA. The extant genera can be distinguished from one another using porosity type, presence or absence of vessel clusters, axial parenchyma type, ray width, and crystal occurrence. The late Eocene woods from Post, Oregon, conform anatomically with those of extant Ulmus. To assess whether fossil woods might be identified to an infrageneric category, selected wood anatomical features of $21 \mathrm{ex}-$ tant species of Ulmus are summarized to evaluate whether any sections within the genus have distinctive anatomy. Porosity type in extant Ulmus is related to leaf longevity; extant evergreen species are diffuse porous and have relatively narrow rays. Other extant Ulmus species are deciduous and predominantly ring porous, only rarely semi-ring porous, with clustered latewood vessels that are tangentially arranged. Sometimes earlywood characteristics have systematic value and allow recognition of groups. However, in some species earlywood characteristics are variable, apparently being much affected by growing conditions. Eastern U.S. species belonging to Sections Chaetoptelea and Trichoptelea of Subgenus Oreoptelea consistently have thick-walled fibers, single rows of small-medium diameter earlywood vessels, and little difference between the diameters of the solitary earlywood vessels and latewood vessels. The late Eocene Ulmus woodii sp. nov. shares more features with this group than any other. Another of these late Post Eocene woods is referable to Ulmus danielii, a species previously known only from the Middle Eocene Clarno Formation. A third fossil wood type resembles diffuse porous Ulmus, but its lower preservational quality obscures some diagnostic features and precludes secure assignment. • Key words: Ulmaceae, Ulmus, Eocene, fossil wood, wood anatomy, John Day Formation.
\end{abstract}

WHEELER, E.A. \& MANCHESTER, S.R. 2007. Review of the wood anatomy of extant Ulmaceae as context for new reports of late Eocene Ulmus woods. Bulletin of Geosciences 82(4), 329-342 (5 figures, 2 tables). Czech Geological Survey, Prague. ISSN 1214-1119. Manuscript received April 16, 2007; accepted in revised form September 17, 2007; issued December 31, 2007. • DOI 10.3140/bull.geosci.2007.04.329

Elisabeth A. Wheeler, Department of Wood and Paper Science, North Carolina State University, Raleigh, N.C. 27605-8005, USA; elisabeth_wheeler@ncsu.edu・Steven R. Manchester, Florida Museum of Natural History, University of Florida, Gainesville, FL 32611, USA; steven@ flmn.ufl.edu

The family Ulmaceae in its current circumscription comprises seven extant genera: Ampelocera, Hemiptelea, Holoptelea, Phyllostylon, Planera, Ulmus, and Zelkova, and at least one extinct genus, Cedrelospermum (Manchester 1989a). Sytsma et al. (2002) found the Ulmaceae (excluding the Celtidaceae) strongly monophyletic. The family has a rich fossil record of fruits, seeds, and leaves (Manchester 1989b, Denk \& Dillhoff 2005), and there are unequivocal Ulmaceae woods from the Tertiary of western North America (e.g., Prakash \& Barghoorn 1961a, 1961b; Wheeler 1978, 2001), Europe (e.g., Sakala 2002), and Asia (e.g., Suzuki \& Hiraya 1989).

Among the objectives of this paper are to review the wood anatomy of extant Ulmaceae and to determine whether variation in wood anatomical features reflects groupings recognized in recent phylogenetic analyses. The review of wood anatomy of extant Ulmaceae provides the context for describing new occurrences of this family among woods from the Late Eocene of Oregon, USA. One of the questions this study addresses is whether subgenera and sections of Ulmus have distinctive wood anatomy so that subgeneric and sectional affinities of isolated fossil wood samples can be determined.

\section{Materials and methods}

The new occurrences of fossil Ulmaceae woods are from a site near Post, Oregon, USA (UF Localiy 279; Wheeler et al. 2006). The specimens occur loose in eroded tuffs and apparently are from the lower part of the John Day Formation. A prominent white tuff outcrops above the wood horizon and contains sanidine crystals that were dated at $36.21 \pm 0.26 \mathrm{MA}(\mathrm{n}=26)$ by ${ }^{40} \mathrm{Ar} /{ }^{39} \mathrm{Ar}$ single crystal fusion 
method (Manchester \& McIntosh 2007). There are no datable tuffs at or immediately below the fossiliferous horizon to provide a maximum age. However, a late Eocene date seems a reasonable approximation of the age of the Post woods.

A diamond lapidary saw was used to cut thick sections (wafers) of cross (transverse), tangential, and radial surfaces. One side of each wafer was smoothed to remove saw marks, and then affixed to a glass slide using 24-hour transparent epoxy. The sections were then ground until they were thin enough $(\mathrm{ca} 30 \mu \mathrm{m})$ so that anatomical details could be seen with transmitted light microscopy. Grinding was done either by hand, using a glass plate and a slurry of carborundum grit or a Buehler petrographic thin section grinding machine. Cover slips were mounted using Canada Balsam to improve clarity for light microscopy. Samples are deposited in the paleobotanical collections of the Florida Museum of Natural History, University of Florida (UF), Gainesville; in this paper individual samples are referred to by their UF sample numbers. To date, we have examined thin sections of 36 samples from UF locality 279. Relationships to extant plants initially were assessed by reference to the InsideWood website (http:insidewood.lib.nesu.edu/search), followed by examination of the literature, images on various web sites, and microscope slides of extant woods from the collections at the University of Florida, National Herbarium of the Netherlands, Harvard University, and North Carolina State University. Appendix I lists the species and samples examined and literature sources for the extant woods. Institutional wood collection abbreviations as per Stern (1988).

Observations and photographs of most of the samples examined for this study are available on the InsideWood site. Descriptions of the fossil wood types from Post generally conform to the IAWA Hardwood Feature List (Wheeler et al. 1989). For vessel tangential diameter, the mean with the standard deviation in parentheses is given, e.g., 116 (21) $\mu \mathrm{m}$.

\section{Extant Ulmaceae}

Metcalfe \& Chalk (1950) and Sweitzer (1971) provided overviews of the anatomy of the family. These and other treatments prior to the 1990s used a broader concept of the Ulmaceae, including the subfamilies Ulmoideae and Celtoideae. Grudzinskaya's (1967) separation of these groups into separate families received further support from cladistic analyses of other morphological and molecular characters (Wiegrefe et al. 1998), leading to the current practice of merging former Celtidaceae with the Cannabaceae, and retaining the Ulmaceae in a narrower sense (Stevens 2001 onwards; Soltis et al. 2005).

Other studies have concentrated on Ulmaceae from a particular region (e.g., China, Zhong et al. 1992; United States, Wheeler et al. 1989). Descriptions and illustrations of Ulmaceae wood also are found in regional wood anatomical surveys (e.g., Europe, Grösser 1977, Schweingruber 1990, Schoch et al. 2004; Japan, FFPRI Wood Identification Database Team 2002 onwards; India, Pearson \& Brown 1932; Israel, Fahn et al. 1986) and in publications concentrating on the recognition of commercially important woods (e.g., Brazier \& Franklin 1961, Kribs 1968, Richter \& Dallwitz 2000).

All Ulmaceae share simple perforation plates, alternate intervessel pitting, vessel-ray parenchyma pits similar in size to intervessel pits (but with variation in how reduced the borders are), predominantly paratracheal axial parenchyma, non-septate fibers with simple pits, rays that are mostly (usually entirely) composed of procumbent cells. Crystals when present are prismatic. Many of these characters are shared with Cannabaceae, however, Cannabaceae (including Celtidaceae) have heterocellular rays.

Selected anatomical characteristics of the genera, based on available material and the literature are summarized in Table 1 and shown in Fig. 1.

The phylogenetic analyses of Wiegrefe et al. (1998) and Sytsma et al. (2002) did not include Phyllostylon, but

Figure 1. Wood anatomy of exant Ulmaceae. A A, B - Ampelocera hottlei. INIFw 432. A - diffuse porous wood. Vessels mostly solitary and with short radial multiples. Axial parenchyma paratracheal (winged-aliform), and marginal. Fibers thick-walled. TS. B - rays mostly 4-5 seriate, axial parenchyma in strands of 4-8. TLS. $・$ C, D - Holoptelea grandis. SJRw 23262. C - diffuse porous wood. Vessels mostly solitary and with short radial multiples. Axial parenchyma paratracheal, winged-aliform and banded confluent. TS. D - rays mostly 3-seriate, locally storied rays, axial parenchyma strands $2-4$. - E-J - Phyllostylon rhamnoides. E - SJRw 782. Diffuse porous wood, vessels tending to a radial arrangement. TS. F - SJRw 23409. Diffuse porous wood, scanty paratracheal to confluent axial parenchyma. TS. G - SJRw 782. Thick-walled vessels and fibers. TS. H - SJRw 782. Crowded alternate intervessel pits, angular in outline with included apertures. TLS. I-SJRw 782. Vessel-ray parenchyma pits with reduced borders. RLS. J-SJRw 23409. Rays mostly 3 -seriate, storied axial parenchyma strands, low rays storied. TLS. $\bullet \mathrm{K}-\mathrm{M}-$ Hemiptelea davidii. Hw 5283 . K - ring porous wood, earlywood zone narrow, latewood vessels in small clusters, thick-walled fibers. TS. L-multiseriate rays more than 10 -seriate, narrow vessels elements and axial parenchyma storied, axial parenchyma strands predominantly of 4 cells. TLS. M - vessel-ray parenchyma pits similar in size to intervessel pits, rounded in outline. RLS. • N-P - Zelkova serrata. TWTw 14915. N - ring porous wood, earlywood zone with 1 row of large pores. TS. O - crystals in idioblasts in rays and in chambered axial parenchyma cells. Storied axial parenchyma, strands predominantly 2 cells. TLS. P - rays composed of procumbent cells, crystals in enlarged ray parenchyma cells. RLS. • Q, R - Planera aquatica. SJRw 11169. Q - diffuse porous wood. Vessels solitary and in small groups, tangential arrangement of vessels not apparent. TS. R - multiseriate rays to 5-6 seriate, axial parenchyma storied, short narrow rays irregularly storied, crystals in axial parenchyma strands. TS $=$ transverse section. $\mathrm{RLS}=$ radial longitudinal section. TLS $=$ tangential longitudinal section. $\bullet$ Scale bars $=500$ $\mu \mathrm{m}$ in $\mathrm{A} ; 200 \mu \mathrm{m}$ in $\mathrm{C}, \mathrm{E}, \mathrm{F}, \mathrm{K}, \mathrm{N}, \mathrm{Q} ; 100 \mu \mathrm{m}$ in B, D, G, J, L, O, P, R; $50 \mu \mathrm{m}$ in H, I, M. 

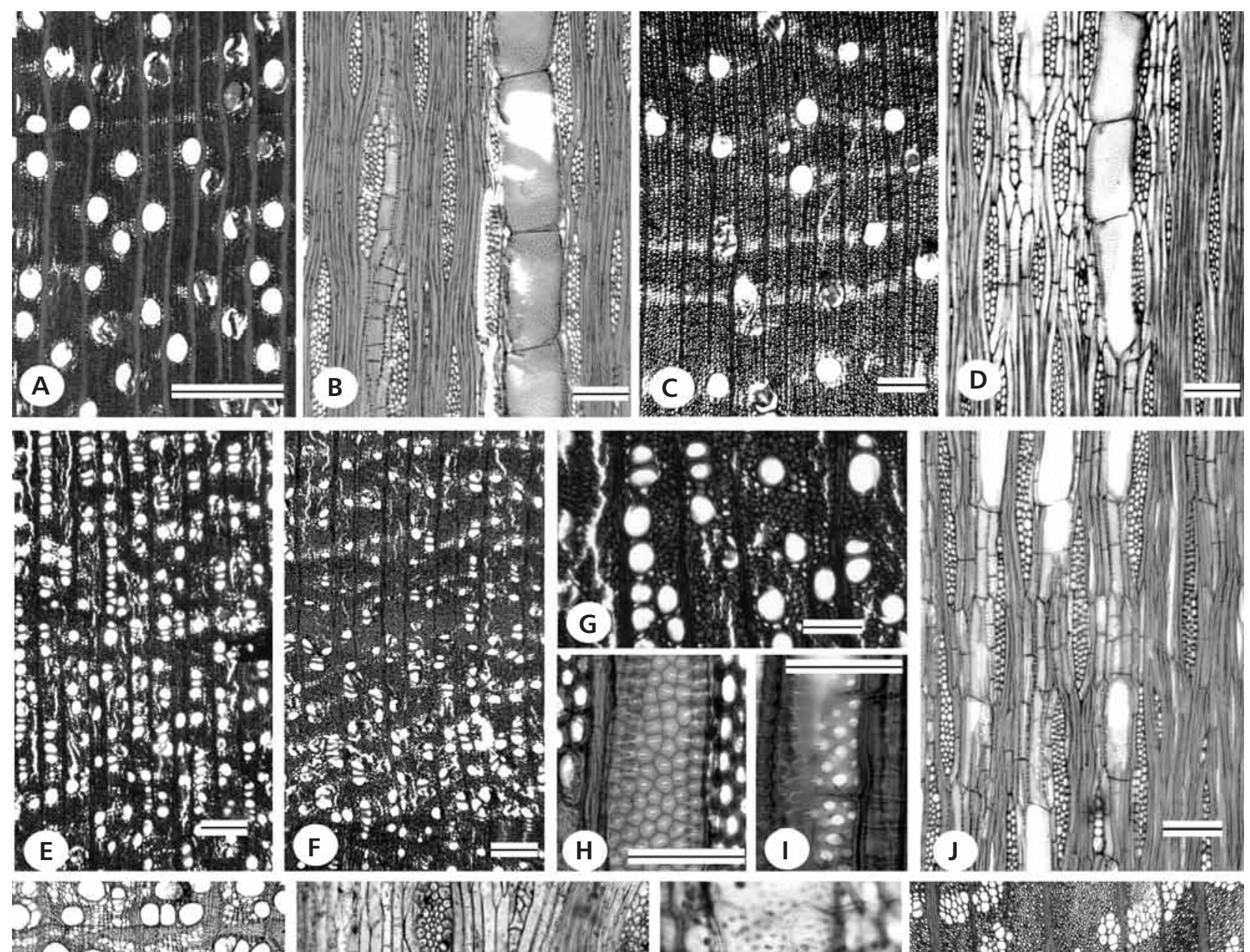
80000
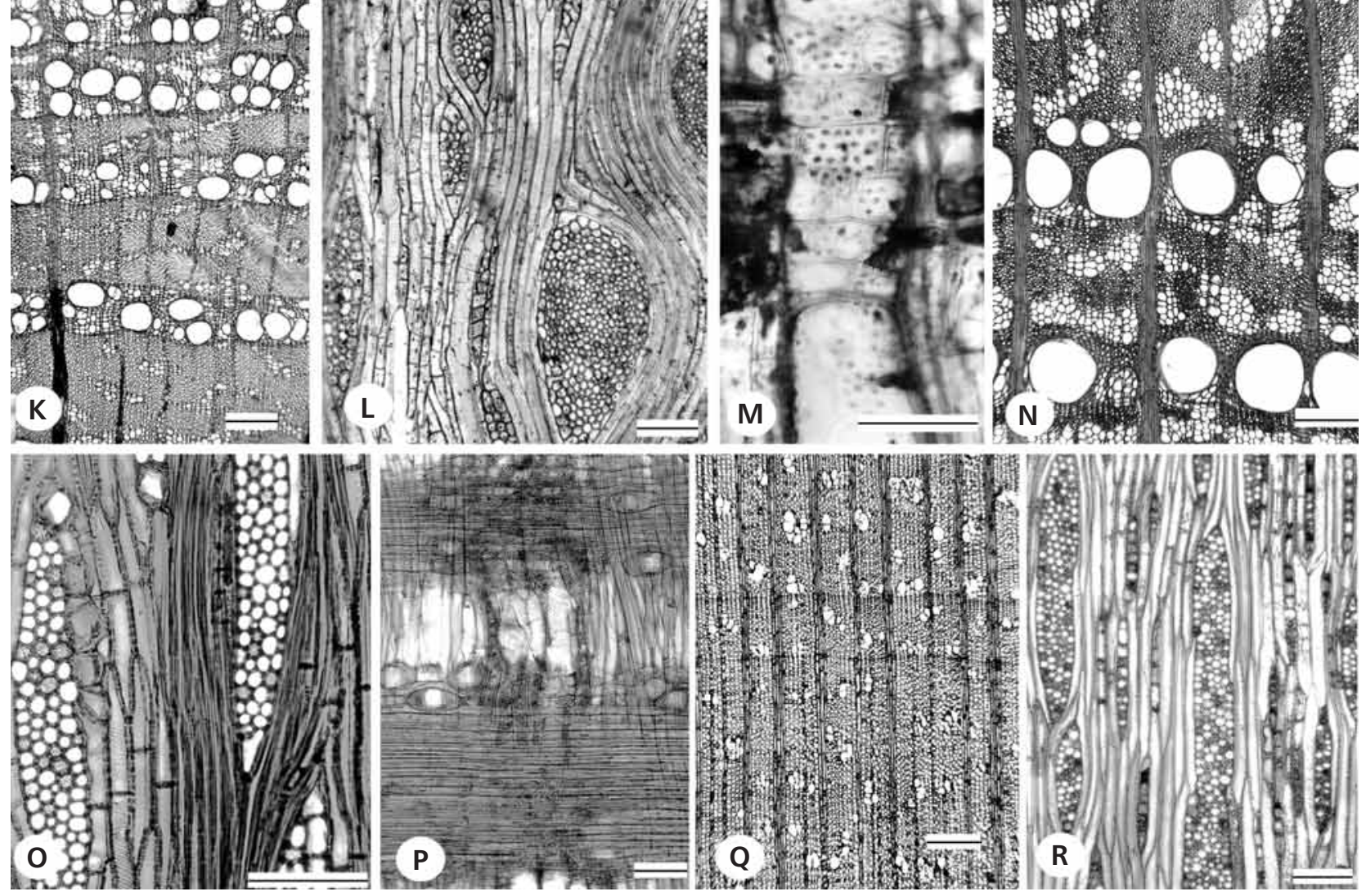
Table 1. Selected wood anatomical characteristics of extant genera of Ulmaceae $\cdot$ Porosity: $\mathrm{DP}=$ diffuse porous, $\mathrm{RP}=$ ring porous, $\mathrm{SRP}=$ semi-ring porous. EW depth = rows of earlywood vessels in ring porous woods. RW = ray width in cell number. Ray type: Ho = homocellular, Het $=$ heterocellular. Storied rays: irreg =irregularly storied. Storied AP $=$ storied axial parenchyma. AP type $=$ axial parenchyma arrangement: vc $=$ vasicentric, para $=$ paratracheal parenchyma intermixed with vessel clusters. Crystals $=$ location of prismatic crystals: $a p=$ axial parenchyma, $r p=$ ray parenchyma, e $=$ enlarged cells. Par. strands = number of cells per axial parenchyma strand.

\begin{tabular}{|c|c|c|c|c|c|c|c|c|c|c|}
\hline Genus & Porosity & $\begin{array}{c}\text { EW } \\
\text { depth }\end{array}$ & Clusters & RW & Ray type & $\begin{array}{l}\text { Storied } \\
\text { rays }\end{array}$ & $\begin{array}{l}\text { Storied } \\
\text { AP }\end{array}$ & AP type & Crystals & $\begin{array}{c}\text { Par. } \\
\text { strands }\end{array}$ \\
\hline Ampelocera & $\mathrm{DP}$ & na & no & $1-4(6)$ & Ho, Het (1 row) & no & no & $\begin{array}{l}\text { vc, aliform (winged), } \\
\text { confluent }\end{array}$ & ap & $4-8$ \\
\hline Holoptelea & DP & na & no & $1-3(4)$ & Ho & irreg & yes & $\begin{array}{l}\text { vc, aliform (winged), } \\
\text { confluent }\end{array}$ & $\begin{array}{c}\text { not } \\
\text { observed }\end{array}$ & 4 \\
\hline Phyllostylon & $\mathrm{DP}$ & na & no & $1-3$ & Ho, Het & irreg & yes & vc, confluent, diffuse & (rp) & $1-2$ \\
\hline Hemiptelea & $\mathrm{RP}$ & $1(2)$ & yes & $1-18$ & Ho, Het (1 row) & no & yes & para & ap, rp & $2-4$ \\
\hline Planera & $\begin{array}{c}\mathrm{DP} \\
(\mathrm{SRP})\end{array}$ & na & yes & $1-6$ & Ho [Het (1 row)] & no & yes & para & (rp) & $2-4$ \\
\hline Ulmus & $\begin{array}{c}\text { DP, } \\
\text { SRP, RP }\end{array}$ & $\begin{array}{l}1 \text { to } \\
\text { multiple }\end{array}$ & yes & $1-8$ & Ho & no & (yes) & para & ap (e) & 4 \\
\hline Zelkova & $\mathrm{RP}$ & 1 & yes & $1-6$ & Ho, Het (1 row) & no & yes & para & ap e, rp e & 2 \\
\hline
\end{tabular}

show the other exclusively tropical genera Ampelocera (distribution: Central and northern South America, Fig. 1A, B) and Holoptelea (distribution $H$. grandis: India, H. integrifolia: Africa, Fig. 1C, D) on a branch separate from other Ulmaceae. The woods of these two tropical genera are distinguished from all other genera of the family by the presence of aliform (usually winged) paratracheal parenchyma, randomly arranged vessels that are solitary and in short radial multiples (but not in clusters), and relatively narrow rays (usually less than 4-seriate). Storied rays were observed in Holoptelea, and a tendency towards locally, irregularly storied rays in Ampelocera.

Phyllostylon (Fig. 1E-J), another wholly tropical genus was resolved as sister to Holoptelea in morphological cladistic analyses, regardless of whether the extinct genus Cedrelospermum was included in the analysis (Manchester \& Tiffney 2001). Phyllostylon, like the other tropical Ulmaceae, is diffuse porous, and has randomly arranged vessels (solitary and in radial multiples) (Fig. 1E, F), and relatively narrow rays (Fig. $1 \mathrm{~J}$ ). It shares with Holoptelea, but not Ampelocera, distinctly storied axial parenchyma, usually with two cells per strand. It is distinct as it has narrow, very thick-walled vessel elements, which sometimes appear to have a radial arrangement (Fig. 1E), axial parenchyma that is not winged-aliform, but scanty paratracheal, vasicentric and confluent, and crystals, when present, are in ray parenchyma. In addition, the rays of Phyllostylon are distinctly storied in some samples (see Richter \& Dallwitz 2000), and irregularly storied in others (Fig. 1J); the latter condition shared with Holoptelea (Fig. 1D).

The aforementioned analysis showed the monotypic Hemiptelea (distribution: China, Korea, Fig. $1 \mathrm{~K}-\mathrm{M}$ ) on a branch separate from Ulmus and Zelkova. The distinctive feature for Hemiptelea is its very broad rays, with maximum ray width exceeding 10 -seriate and some rays nearly
20 cells wide. Minaki et al. (1988, Fig. 1L) described the rays as having sheath cells, which is unusual for Ulmaceae, but common in Cannabaceae s.l. Crystals are reported to occur in both ray and axial parenchyma, with crystal-containing cells not being enlarged.

Wiegrefe et al. (1998) recovered a trichotomy of Planera, Ulmus, and Zelkova, without any resolution between these three genera. Manchester \& Tiffney's (2001) analyses show Planera and Ulmus forming a clade that is sister to Zelkova. Although apparently closely related, these three genera differ in their wood anatomical characteristics.

Zelkova (distribution: S Europe, western Asia, Soviet Far East, China, eastern Asia, Fig. 1N-P) is ring porous, with single rows of wide earlywood vessels, and is the only Ulmaceae with crystals in inflated ray cells (Fig. 1P); crystals are sometimes also present in short strands of enlarged chambered axial parenchyma.

Planera (distribution: north-central, south-central and southeastern U.S., Fig. 1Q, R) is diffuse porous to semiring porous and when crystals are present they are in ray parenchyma. Storied structure is present, with local storying of vessel elements, axial parenchyma, and short rays.

Ulmus is the most geographically widespread (Asia, Europe, North America) and the most speciose genus. There is debate over the number of Ulmus species (25-45), especially about species delimitations in Eastern Europe, Central Asia and the Far East. Table 2 gives data for selected wood anatomical features, using the sectional classification of Denk \& Dillhoff (2005) that was based on the morphological study of Grudzinskaya (1979) and the combined morphological-molecular study of Wiegrefe et al. (1994). Figs 2 and 3 illustrate some of the variation within Ulmus. Wiegrefe et al. studied 14 species of the genus. We had wood samples or information from the literature on all but one (U. glaucescens) 

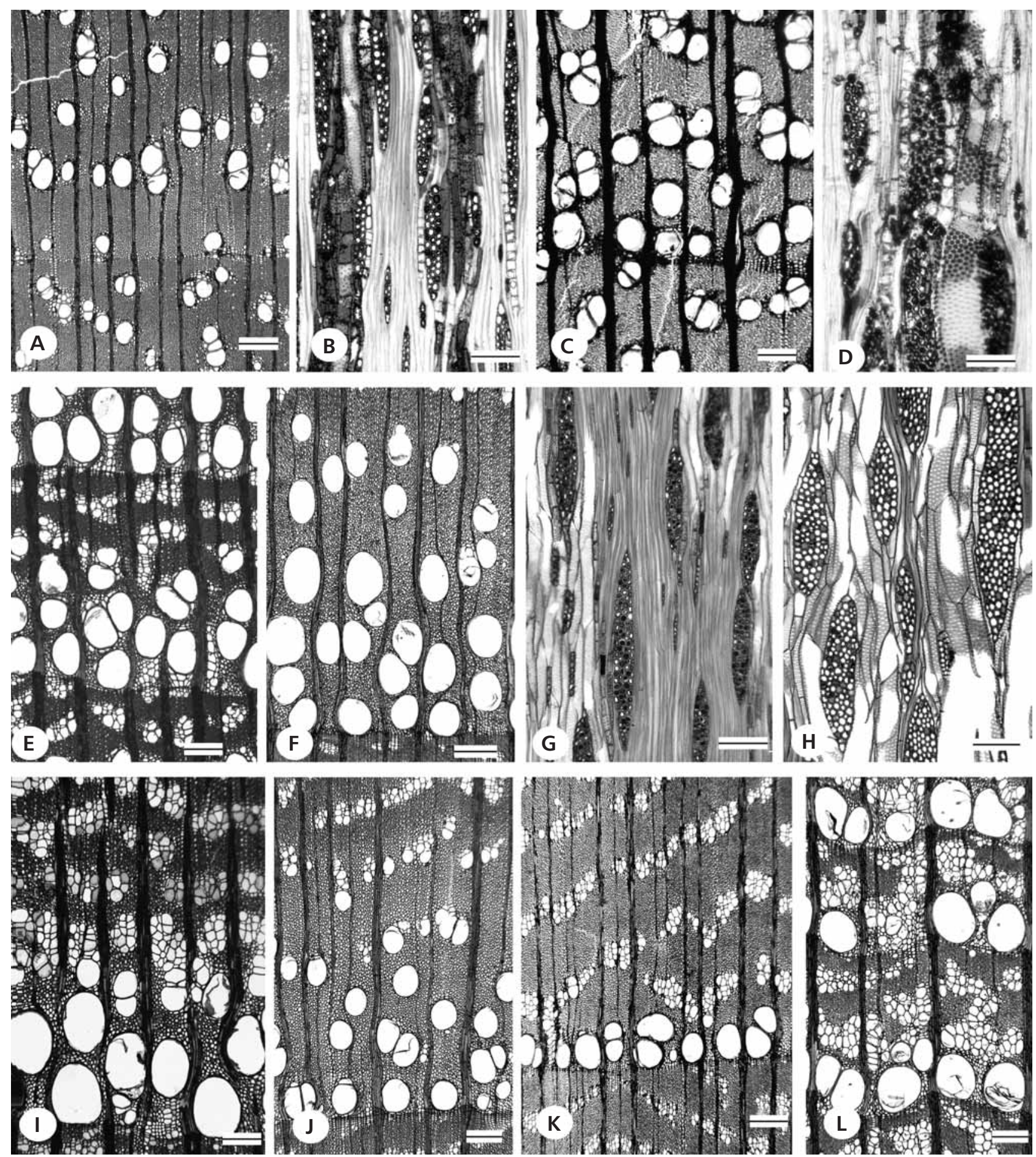

Figure 2. Wood anatomy of extant Ulmus. • A, B - Ulmus lanceifolia. CAFw 6813. A - diffuse porous wood. Vessels solitary and in short radial multiples, some regions with vessels showing a slight tendency to a tangential arrangement, scanty paratracheal, vasicentric, and discontinuous marginal parenchyma. TS. B - rays 1-4 seriate, chambered crystalliferous axial parenchyma, more than 4 chambers. TLS. $\bullet$ C, D - U. mexicana. USw 15582. $\mathrm{C}$ - diffuse porous wood. Vessels solitary and in short radial multiples, some oblique groupings and occasional clusters. Scanty paratracheal, vasicentric and marginal parenchyma. TS. D - multiseriate rays mostly 4 cells wide, chambered crystalliferous axial parenchyma, crowded alternate pitting. TLS. - E - U. parvifolia. TWTw 1962. Earlywood zone 2-3 pores deep. Latewood fibers thick-walled. $\cdot$ F-H - U. rubra. F - BWCw 8482. Earlywood zone with multiple rows and a transition to narrow vessels in clusters. TS. G-BWCw 8482. Rays slender. H-BWCw 8167. Rays stocky. $\bullet$ I - U. glabra. SJRw 19686. Earlywood zone 2 pores deep. • J, K - U. minor. J - FHOw 2498. Earlywood zone broad. K - SJRw 9687. Earlywood pore zone 1(-2) pores deep. - $\mathrm{L}-$ U. macrocarpa. $\mathrm{CAFw}$ 5321. Earlywood zone 1 pore deep. $\mathrm{TS}=$ transverse section. $\mathrm{RLS}=$ radial longitudinal section. TLS = tangential longitudinal section. $\bullet$ Scale bars $=200 \mu \mathrm{m}$ in A, C, E, F, I-L; $100 \mu \mathrm{m}$ in B, D, G, H. 
Table 2. Selected wood anatomical characteristics of extant Ulmus species. Porosity: $\mathrm{DP}=$ diffuse porous, $\mathrm{RP}=$ ring porous, $\mathrm{SRP}=$ semi-ring porous. EW Zone $=$ number rows of earlywood vessels, $\mathrm{c}=$ continuous row, $\mathrm{d}=$ discontinuous. EW.MTD = mean tangential diameter of earlywood vessels, standard deviation in parentheses. Fib. Wall = thickness of fiber walls. RW = ray width in cell number. MRH $=$ mean ray height in $\mu \mathrm{m}$, standard deviation in parentheses. Storied Par. = storied axial parenchyma: irreg = irregularly storied. Crystals = location of prismatic crystals: ap = chambered axial parenchyma, followed by number of chambers, $\mathrm{rp}=$ ray parenchyma, $\mathrm{ab}=\mathrm{absent}$.

\begin{tabular}{|c|c|c|c|c|c|c|c|c|c|}
\hline Taxa & Porosity & $\begin{array}{l}\text { EW } \\
\text { Zone } \\
\end{array}$ & EW.MTD & Fib.Wall & RW & MRH & $\begin{array}{l}\text { Storied } \\
\text { Par. }\end{array}$ & Crystals & $\begin{array}{c}\text { Par. } \\
\text { Strands } \\
\end{array}$ \\
\hline \multicolumn{10}{|l|}{ Subgenus Ulmus } \\
\hline Section Microptelea & East Asia & & & & & & & & \\
\hline U. parvifolia Jacq. & $\mathrm{RP}$ & $3+, \mathrm{c}$ & $182(18)$ & thick & 1 to $6(7)$ & $353(119)$ & $\begin{array}{c}\text { not } \\
\text { observed }\end{array}$ & ap & 2 to 8 \\
\hline Section Ulmus & \multicolumn{9}{|c|}{ East Asia, Europe, North America } \\
\hline U. rubra Muhl. & $\mathrm{RP}$ & $3+$ & $\begin{array}{l}161(26)- \\
231(38)\end{array}$ & thin-thick & 1 to $5(7)$ & $\begin{array}{l}222(92)- \\
342(137)\end{array}$ & irreg & rare, ap & 4 \\
\hline U. glabra Huds. & $\mathrm{RP}$ & $\begin{array}{l}\text { (1) } 2-3 \text {, } \\
\text { c }\end{array}$ & $\begin{array}{l}209(42)- \\
224(41)\end{array}$ & thin-thick & 1 to 6 & $421(120)$ & irreg & $\begin{array}{l}\text { ap, } 4 \text { to } \\
12\end{array}$ & (2) 4 \\
\hline U. minor Mill. & $\mathrm{RP}$ & $(1)-2, \mathrm{c}$ & $\begin{array}{l}182(31)- \\
226(35)\end{array}$ & thin-thick & 1 to $6(7)$ & $\begin{array}{l}316(143)- \\
382(107)\end{array}$ & irreg & $\begin{array}{c}\text { not } \\
\text { observed }\end{array}$ & 4 \\
\hline U. macrocarpa Hance & $\mathrm{RP}$ & $1-3, \mathrm{c}$ & $170-210$ & thin-thick & $\begin{array}{c}1-7, \\
\text { 1s present, } \\
2 \text { width classes }\end{array}$ & $366(110)$ & irreg & $\begin{array}{l}\text { rare, ap. } 8 \\
\text { chambers }\end{array}$ & 2 to 4 \\
\hline $\begin{array}{l}\text { U. davidiana Planch. var. } \\
\text { japonica (Sarg. ex Rehder) Nakai }\end{array}$ & $\mathrm{RP}$ & $1-2, \mathrm{~cd}$ & $\begin{array}{l}143(23)- \\
240\end{array}$ & thin-thick & 1 to 5 & $404(167)$ & irreg & ap & 4 \\
\hline U. laciniata (Trautv.) Mayr & $\mathrm{RP}$ & $1-2, \mathrm{c}$ & $167-195$ & thin-thick & 1 to 7 & $426(228)$ & irreg & ap & 2 to 4 \\
\hline U. pumila L. & $\mathrm{RP}$ & $3+$ & $140-161$ & $\begin{array}{l}\text { medium- } \\
\text { thick }\end{array}$ & 1 to 7 & $\begin{array}{l}329(113)- \\
423(202)\end{array}$ & yes & $\begin{array}{c}\text { not } \\
\text { observed }\end{array}$ & 4 \\
\hline \multicolumn{10}{|l|}{ Subgenus Oreoptelea } \\
\hline Section Blepharocarpus & \multicolumn{9}{|c|}{ Europe, North America } \\
\hline U. americana $\mathrm{L}$. & $\mathrm{RP}$ & $\begin{array}{c}1 \text { row, } \\
\mathrm{c}\end{array}$ & $\begin{array}{l}147(21)- \\
237(41)\end{array}$ & thin-thick & 1 to $5(6)$ & $\begin{array}{l}183(66)- \\
373(158)\end{array}$ & irreg & $\begin{array}{l}\text { ab to rare, } \\
\text { ap }\end{array}$ & 4 \\
\hline U. laevis Pall. & $\mathrm{RP}$ & $\begin{array}{c}1 \text { row, } \\
\text { c }\end{array}$ & $206(37)$ & medium & 1 to 5 & $386(229)$ & irreg & ap & 4 \\
\hline Section Chaetoptelea & \multicolumn{9}{|c|}{ East Asia, North America } \\
\hline U. mexicana (Liebm.) Planch. & DP & $\mathrm{n} / \mathrm{a}$ & $163(19)$ & $\begin{array}{l}\text { thick-v. } \\
\text { thick }\end{array}$ & 4 to 5 & $283(54)$ & no & $\begin{array}{l}\text { ap, } 4 \text { to } \\
12\end{array}$ & 4 \\
\hline U. alata Mill. & $\mathrm{RP}$ & $1, \mathrm{~d}$ & $\begin{array}{l}112(23)- \\
143(28)\end{array}$ & $\begin{array}{l}\text { thick-v. } \\
\text { thick }\end{array}$ & 1 to $6(7)$ & $\begin{array}{l}168(76)- \\
438(208)\end{array}$ & irreg & ap & 2 to 4 \\
\hline Section Trichoptelea & \multicolumn{9}{|c|}{ North America } \\
\hline U. thomasii Sarg. & $\mathrm{RP}$ & $1, \mathrm{~d}$ & $\begin{array}{l}125(28)- \\
162(28)\end{array}$ & $\begin{array}{l}\text { thick-v. } \\
\text { thick }\end{array}$ & 6 to 7 & $\begin{array}{l}211(76)- \\
354(168)\end{array}$ & yes & (ap) & 4 \\
\hline U. crassifolia Nutt. & "RP” & $1, \mathrm{~d}$ & $\begin{array}{l}62(13)- \\
118(16)\end{array}$ & $\begin{array}{l}\text { thick-v. } \\
\text { thick }\end{array}$ & 4 to 6 & $\begin{array}{l}230(86)- \\
446(260)\end{array}$ & yes & ap, 2 , e & 4 \\
\hline U. serotina Sarg. & $\mathrm{RP}$ & $1, \mathrm{~d}$ & $\begin{array}{l}115(20)- \\
137(23)\end{array}$ & $\begin{array}{l}\text { thick-v. } \\
\text { thick }\end{array}$ & 4 to 6 & $\begin{array}{l}187(66)- \\
348(142)\end{array}$ & yes & ap, $2, \mathrm{e}$ & 4 \\
\hline
\end{tabular}

Subgenus unknown

Section Lanceifolia

East Asia

U. lanceifolia Roxb. ex Wall.

DP $\quad \mathrm{n} / \mathrm{a} \quad(103)-135$

thick $1-4,1$ rare

$300(78)$

irreg

ap, 10-12 2 to 8

Subgenus and section not given in GRIN or Wiegrefe et al.

Europe

\begin{tabular}{|c|c|c|c|c|c|c|c|c|c|}
\hline U. procera Salisb. & $\mathrm{RP}$ & $1-2, \mathrm{c}$ & $\begin{array}{c}181(32)- \\
193(20)\end{array}$ & thin-thick & 6 to 7 & $\begin{array}{l}328(77)- \\
430(146)\end{array}$ & $\begin{array}{c}\text { not } \\
\text { observed }\end{array}$ & $\begin{array}{c}\text { not } \\
\text { observed }\end{array}$ & 2 to 4 \\
\hline \multicolumn{10}{|l|}{ India, Nepal } \\
\hline U. wallichiana Planch. & $\mathrm{RP}$ & $1, \mathrm{c}$ & $\begin{array}{c}{[\max . \text { TD }} \\
\text { ew }>225 \\
\mu \mathrm{m}]\end{array}$ & thin-thick & 1 to 7 & $\begin{array}{c}\text { range } \\
140-700\end{array}$ & $\begin{array}{c}\text { not } \\
\text { observed }\end{array}$ & $\begin{array}{c}\text { not } \\
\text { observed }\end{array}$ & 2 to 4 \\
\hline \multicolumn{10}{|l|}{ East Asia } \\
\hline U. castaneifolia Hemsl. & $\begin{array}{l}\text { RP / } \\
\text { SRP }\end{array}$ & $1(\mathrm{~d})$ & $145-150$ & $\begin{array}{l}\text { thin-med. } \\
\text { thick }\end{array}$ & 1 to 4,5 & $\begin{array}{l}237(76)- \\
321(113)\end{array}$ & yes & ap (e), rp & 2 to 4 \\
\hline U. changii W.C. Cheng & $\mathrm{RP}$ & $1(2) c$ & 200 & thick & 1 to 5 & $302(120)$ & (irreg.) & ap (e) & 2 \\
\hline U. uyematsui Hayata & $\mathrm{RP}$ & $1, \mathrm{~d}$ & 190 & thin-thick & 1 to 5 & $390(140)$ & no & $\begin{array}{c}\text { not } \\
\text { observed }\end{array}$ & 4 \\
\hline
\end{tabular}



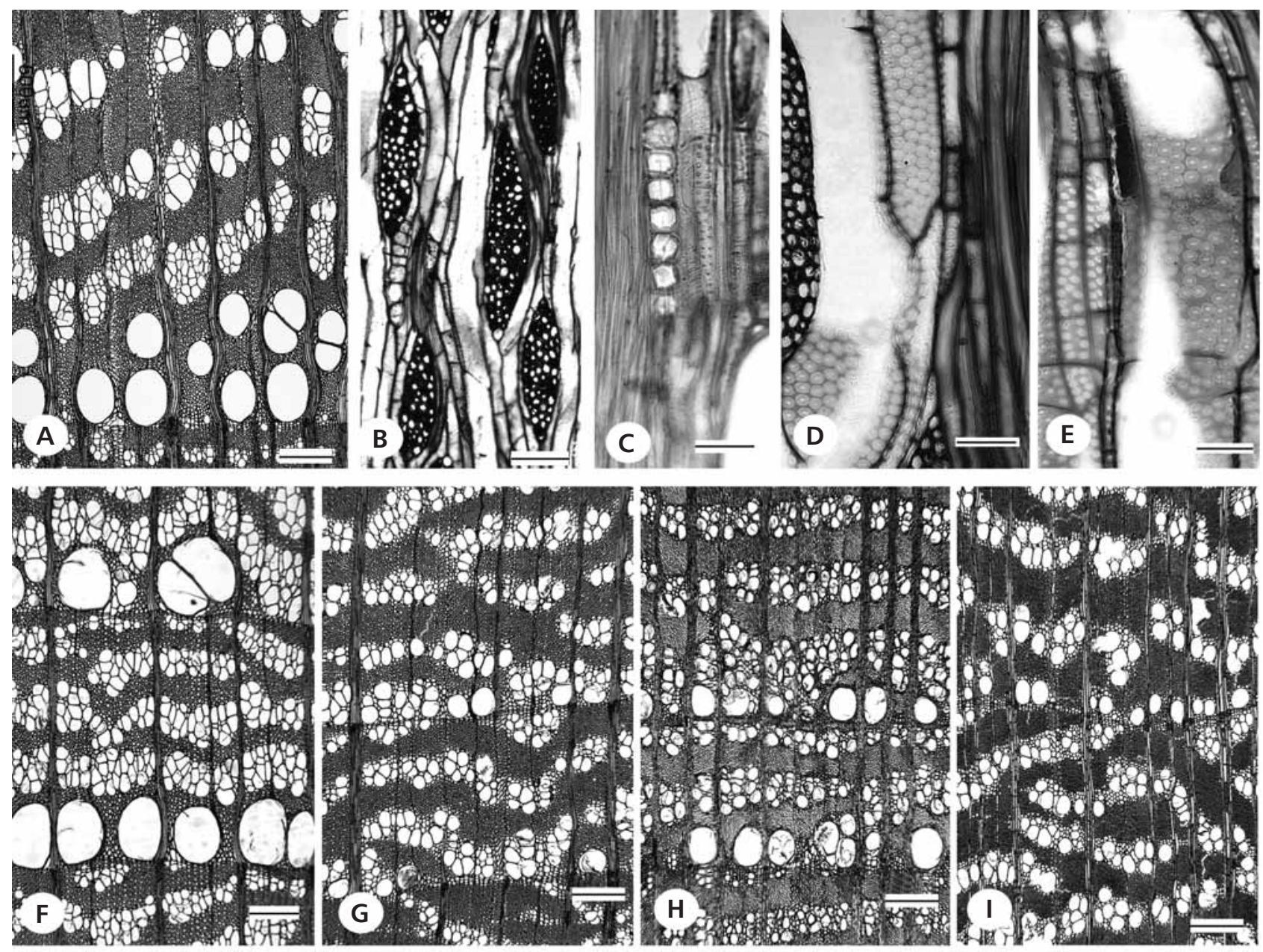

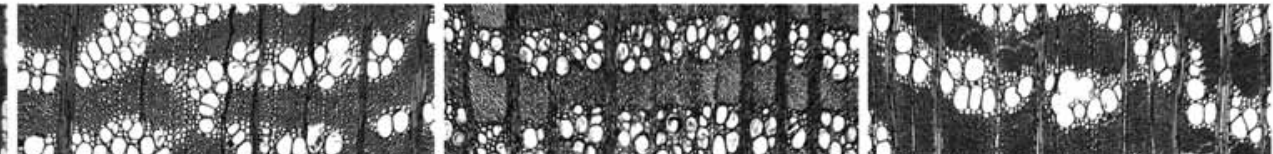

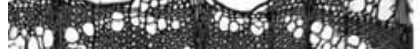

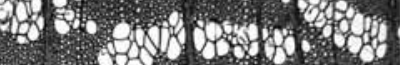

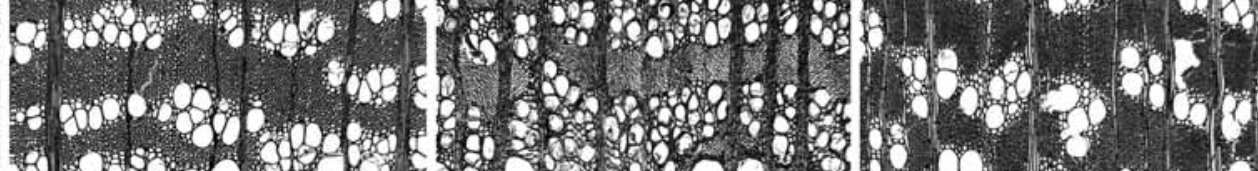

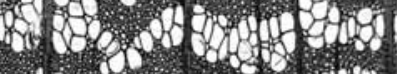

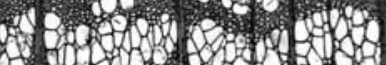
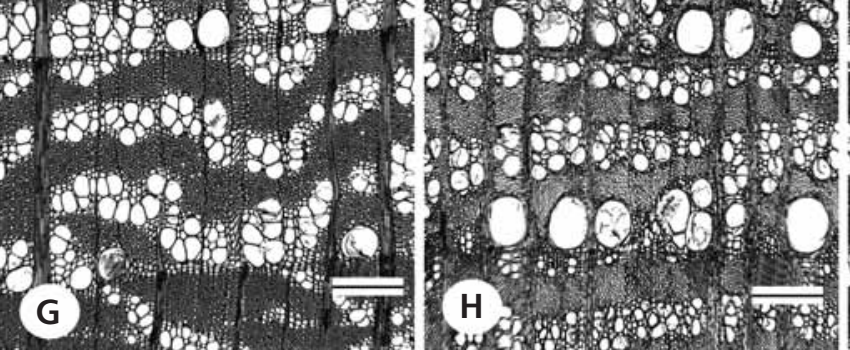
0800,0000

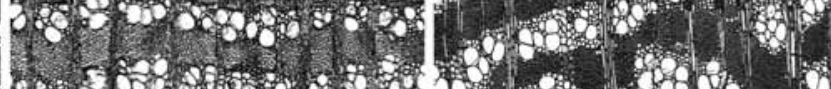

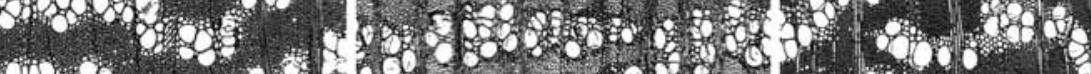

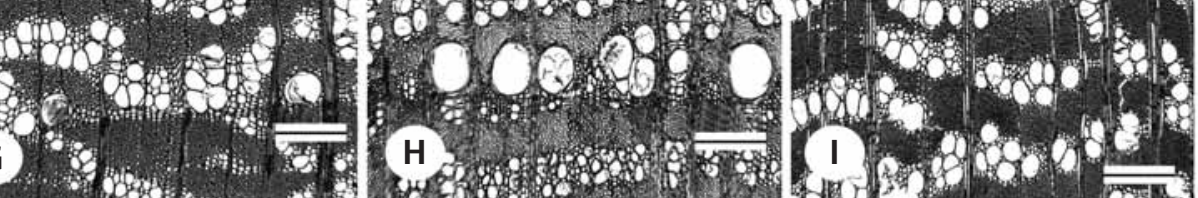
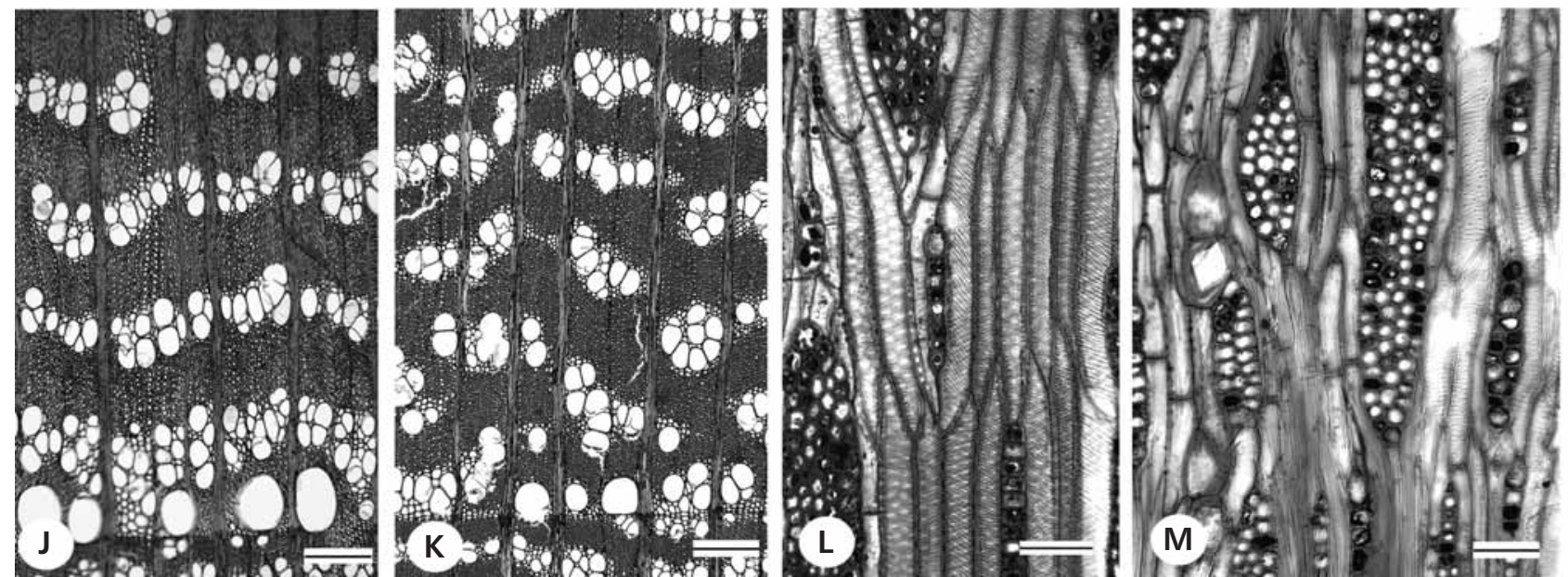

Figure 3. Wood anatomy of extant Ulmus. • A - Ulmus davidiana var. japonica. TWTw 18443. Earlywood pore zone 1-2 pores deep. • B - U. glabra. SJRw 19686. Chambered crystalliferous axial parenchyma. TLS. $\bullet$ C - U. macrocarpa. CAFw 5321. Chambered crystalliferous axial parenchyma. RLS. - D, E - U. procera. Hw 33263. Intervessel pits crowded and polygonal in outline. TLS. E - intervessel pits rounded in outline. RLS. - F - Ulmus americana. BWCw 8014. Continuous row of wide earlywood vessels. $\bullet \mathrm{G}-$ U. alata. BWCw 8218 . $\bullet \mathrm{H}-$ U. serotina. Hw 33267 . $\bullet \mathrm{I}-$ U. crassifolia BWCw 8559. Solitary pores in earlywood with diameter similar to latewood pores. $\bullet$ J- L $-U$. thomasii. J - BWCw 8481. Earlywood zone with a single row of enlarged pores. TS. K - BWCw 8635. Earlywood zone with pores near similar in diameter to latewood pores. TS. L - BWCw 8635. Storied structure. TLS. $\bullet$ M - U. crassifolia. SJRw 11927 . Homocellular rays, mostly 4-5 seriate, large solitary prismatic crystals in short strands of chambered axial parenchyma. TLS. TS $=$ transverse section. $\mathrm{RLS}=$ radial longitudinal section. TLS $=$ tangential longitudinal section. $\bullet$ Scale bars $=200 \mu \mathrm{m}$ in $\mathrm{A}, \mathrm{F}-\mathrm{K}$; $100 \mu \mathrm{m}$ in $\mathrm{B} ; 50 \mu \mathrm{m}$ in $\mathrm{C}-\mathrm{E}, \mathrm{L}, \mathrm{M}$. 
of those species, and data for an additional 7 species. We referred to the USDA's GRIN Taxonomy for Plants (http://www.ars-grin.gov/cgi-bin/npgs/html/tax_search.p) for information on sectional classifications of species not examined by Wiegrefe et al. (1994). However, the sectional classification of some species was not given by GRIN, and there is a need for more comprehensive phylogenetic analyses of the genus. Names, including synonyms, of the European and east Asian species are those used in Flora Europaea (Flora Europaea Editorial Committee, http://rbg-web2.rbge.org.uk/FE/fe.html) and Flora of China (Liguo et al. 2003).

The two evergreen species examined (U. lanceifolia, Fig. 2A, B, U. mexicana, Fig. 2C, D) are both diffuse porous. The deciduous species are semi-ring porous to, more commonly, ring porous. The ring porous species vary in the number of rows of earlywood vessels and in the spacing between those vessels (Figs 2, 3). Some species (e.g., Ulmus americana and U. laevis) have continuous, single rows of earlywood vessels; others have multiple (3 or more) rows (e.g., U. rubra). The latewood vessels of ring porous species are in clusters arranged in tangential bands, with the bands varying from straight to wavy. These latewood vessel elements have helical thickenings along their entire length. Although perforation plates are typically simple, both Sweitzer (1971) and Zhong et al. (1992) observed the rare occurrence of narrow vessel elements with scalariform perforation plates with 1-2 bars. Intervessel pits are alternate and circular to polygonal in outline, with included apertures. Pit shape usually is polygonal in outline on tangential walls (Fig. 3D), and circular to oval on radial walls (Fig. 3E). Individual intervessel pit sizes usually are 5-10 $\mu \mathrm{m}$, with vessel-ray parenchyma pits being similar in size or slightly smaller, but with reduced borders. Widely spaced, thin-walled tyloses are often present in the wider vessels.

Vascular tracheids occur intermixed with vessel clusters. Fibers are non-septate and without obvious pits. Axial parenchyma is paratracheal intermixed with the vessels in the clusters and tangential bands; strands usually have 4 cells.

There is variation in whether there is distinct local storying of vessel elements, vascular tracheids and axial parenchyma. Some of this variation may be affected by whether the tangential section shows earlywood or latewood.

Rays are predominantly homocellular, composed entirely of procumbent cells, sometimes rays near the growth ring boundary have some marginal square cells. Most are multiseriate, usually between 4-7 cells wide (Figs 2G, H, 3B, M). Ray shape varies from slender to fusiform, rays in the vessel / vascular tracheid / parenchyma bands often appear wider than when in the fiber regions. In many species there appears to be a tendency towards two ray sizes. Uniseriate rays are invariably low, mostly less than 10 cells high. Multiseriate ray height averages less than $500 \mu \mathrm{m}$ (168 $\mu \mathrm{m}$ to $426 \mu \mathrm{m})$.

Crystals, when present, occur in chambered axial parenchyma strands, often abutting the rays, with variation in whether the cells are enlarged and in the number of chambers (Fig. 3B, C, M).

\section{Comments on the infrageneric taxa}

\section{Subgenus Ulmus}

Section Microptelea. - It would be difficult to assign an isolated piece of wood to only this section as it is not possible to state with certainty that the multiple rows (3+) of earlywood pores, lack of crystals and lack of obvious storied structure observed in two samples of $U$. parvifolia (Fig. 2E) are consistent features for this section.

Section Ulmus (Figs 2F-2L, 3A-E, Table 2). - There is considerable variation in Section Ulmus and for the most part considerable difficulty in distinguishing the species from one another. The North American Ulmus rubra is consistent sample to sample in having a broad earlywood zone (Fig. 2F), which distinguishes it from the other species of this section that Wiegrefe et al. (1994) examined and which typically have 1-3 rows of earlywood vessels. Their phylogenetic analysis showed U. rubra on a branch separate from other Section Ulmus species. Three of the 4 Ulmus pumila L. samples we examined had an earlywood zone 3 rows deep. We recommend that this species be included in future phylogenetic analyses to see if it is more closely related to $U$. rubra than to other species.

While some samples of all species in Section Ulmus have an earlywood pore zone at least two pores deep, some samples of some species have a single row (Fig. 2L), a condition shared with Subgenus Oreoptelea, Section Blepharocarpus. Two species that show this variation in earlywood characteristics are Ulmus minor (Fig. 2J, K) and U. laciniata (TWTw 18497, TWTw 18696 of FFPRI Wood Database of Japanese Woods, http://f030991.ffpri.affrc.go.jp/index-E1.html).

Characteristics of two commercially important European species of this section, i.e., Ulmus glabra (Fig. 2I) and U. minor Mill. (Fig. 2J, K) were reviewed by Brazier \& Franklin (1961), Grösser (1977), and Schoch et al. (2004). Schoch et al. (2004) show multiple specimens on their Microscopic Wood Anatomy website and conclude that these two species cannot be distinguished; both usually have an earlywood zone (1) 2-3 vessels deep, rays are usually 4-5 seriate. Brazier \& Franklin (1961) commented that rays of $U$. glabra often exceed $1 \mathrm{~mm}$ in height, but none of the samples we examined had rays that high. 

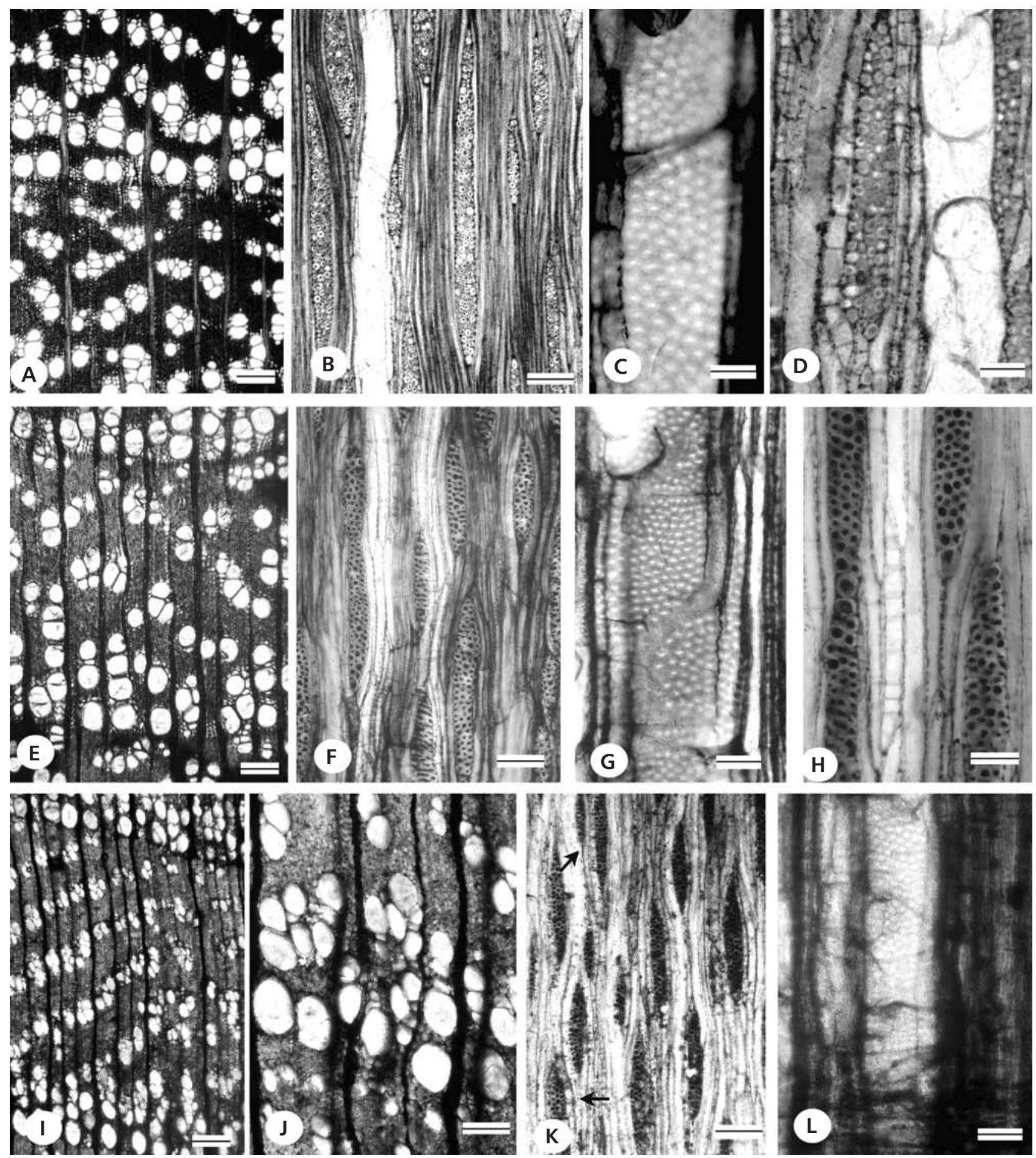

Figure 4. Wood anatomy of Eocene Ulmus woodi sp. nov. • A-D - UF 24549. A - vessels in clusters, latewood vessels in diagonal to tangential arrangement, thick-walled fibers. B - homocellular rays, mostly 4 cells wide. C - crowded alternate pitting, included apertures. D - crystalliferous axial parenchyma strands adjacent to ray, thin-walled tyloses. • E-H - UF 24544 (Holotype). E - vessels in clusters, arranged in diagonal to wavy tangential bandst. $\mathrm{F}$ - homocellular rays, mostly 4 cells wide, storied axial parenchyma. $\mathrm{G}$ - crowded alternate pitting, with included apertures, vessel-axial parenchyma pits of similar size as intervessel pitting and with reduced borders. $\mathrm{H}$ - chambered crystalliferous axial parenchyma strand. $\bullet$ I-L - UF 34457 . I - vessels in clusters, in diagonal to wavy tangential bands. J - earlywood zone. $\mathrm{K}$ - rays mostly 3 to 4 cells wide, chambered axial parenchyma strands (arrows). $\mathrm{L}$ - crowded alternate intervessel pitting, thin-walled tyloses. TS $=$ transverse section. $\mathrm{RLS}=$ radial longitudinal section. TLS $=$ tangential longitudinal section. $\bullet$ Scale bars $=200 \mu \mathrm{m}$ in A, E, I; $100 \mu \mathrm{m}$ in B, F, J, K; $50 \mu \mathrm{m}$ in C, D, G, H, L. 
Crystals are rare in this section, and were not observed in most samples. When present, they occur in axial parenchyma strands that usually have 8 or more chambers, and are not greatly enlarged (Fig. 3B, C,).

\section{Subgenus Oreoptelea}

We observed more consistency in species characteristics in this subgenus than in Subgenus Ulmus (Table 2). All the ring porous species have single rows of earlywood vessels, occasionally, in very wide growth rings of some samples of Section Blepharocarpus parts of the earlywood will have more than 1 row.

Section Blepharocarpus. - Ulmus americana (Fig. 3F) and $U$. laevis have nearly continuous, single rows of wide earlywood pores. Maximum earlywood pore diameters frequently exceed $200 \mu \mathrm{m}$. Fiber walls are thin to medium-thick, never very thick walled.

Section Chaetoptelea (Figs 2C, D, 3G). - Denk \& Dillhoff (2005) include U. mexicana (Fig. 2C, D) and U. alata (Fig. $3 \mathrm{G}$ ) in this section. The evergreen $U$. mexicana is distinct as it is diffuse porous. However, Ulmus alata resembles wood of Section Trichoptelea more than it does wood of $U$. mexicana.

Section Trichoptelea (Fig. 3H-M). - The three species of this section are similar in having earlywood vessels in a single row (Fig. 3H-K) and typically less than $150 \mu \mathrm{m}$ in diameter. The rows of earlywood vessels usually are discontinuous. Distinct storied structure is common (Fig. 3L). Crystals, when present, are in short strands of enlarged chambered axial parenchyma cells (Fig. 3M). Some samples of Ulmus crassifolia do not have distinct earlywood (Fig. 3I); they differ from the evergreen species that are diffuse porous, as $U$. crassifolia has vessel clusters that are in relatively broad wavy tangential bands. Distinctly storied axial parenchyma occurs in all species of the section.

\section{Subgenus not assigned}

Section Lanceifolia. - The subgeneric position of this East Asian section is unclear. Ulmus lanceifolia is evergreen and diffuse porous. There are some vessel clusters and a tendency to a tangential arrangement and crystals are common in axial parenchyma strands (Fig. 2A, B).

Table 2 also gives selected information for species not analyzed by Wiegrefe et al. (1998) nor mentioned by Denk \& Dillhoff (2005). This information is based on only 1 or 2 samples of each species, so whether they consistently have a distinct combination of features cannot be confirmed. Ulmus uyematsuii is noteworthy for having single discontinuous rows of earlywood vessels which have a maximum diameter of $>200 \mu \mathrm{m}$. Ulmus castaneifolia shares with the eastern U.S. Section Trichoptelea crystals in enlarged axial parenchyma cells and has earlywood vessel diameters comparable to those seen in that group. This species is also remarkable within Ulmus for commonly having crystals in ray parenchyma.

\section{Late Eocene Ulmaceae woods from Post, Oregon, U.S.A.}

Ulmus L.

\section{Ulmus woodii sp. nov.}

Figure 4A-L

Description. - Growth rings distinct.

Semi-ring porous. Vessels solitary (rounded in outline) and in radial multiples of 2-3 in earlywood, closely spaced, earlywood zone broad, more than 2-3 earlywood vessels deep, with a gradual transition to latewood; latewood vessels in radial multiples and occasional clusters, diagonal arrangement at time tending to wavy tangential bands, tangential arrangement more obvious in wider growth rings. Mean tangential diameter of earlywood vessels 116 (21)-125 (21), range 60-160 $\mu \mathrm{m}$. Perforations exclusively simple; intervessel pits crowded alternate, polygonal in outline, with included apertures. Vessel-ray parenchyma pits similar in size to intervessel pits, but with reduced borders. Vessel elements 274 (35)-332 (26) $\mu \mathrm{m}$ long. Thinwalled tyloses present, widely spaced.

Axial parenchyma paratracheal, intermixed with vessel elements and vascular tracheids, usually 4 cells per strand.

Fibers non-septate, pits not obvious, thick-walled; narrow elements with crowded alternate pits (likely vascular tracheids).

Rays mostly 3-5 seriate, uniseriates not common; homocellular, composed of procumbent cells. Multiseriate ray height averages 402 (120)-667 (214), range 320-1200 $\mu \mathrm{m}$, 5-7 per mm.

Solitary prismatic crystals in chambered axial parenchyma strands, up to 12 chambers.

Storied structure: narrow vessel elements / vascular tracheids, and axial parenchyma strands tending to be locally storied.

Spiral thickenings not observed.

Material. - UF 24544, diameter $>40 \mathrm{~cm}$ (Holotype designated here, Fig. 4E, F); UF 24549, diameter $>40 \mathrm{~cm}$; UF 34457 , diameter $>40 \mathrm{~cm}$. 

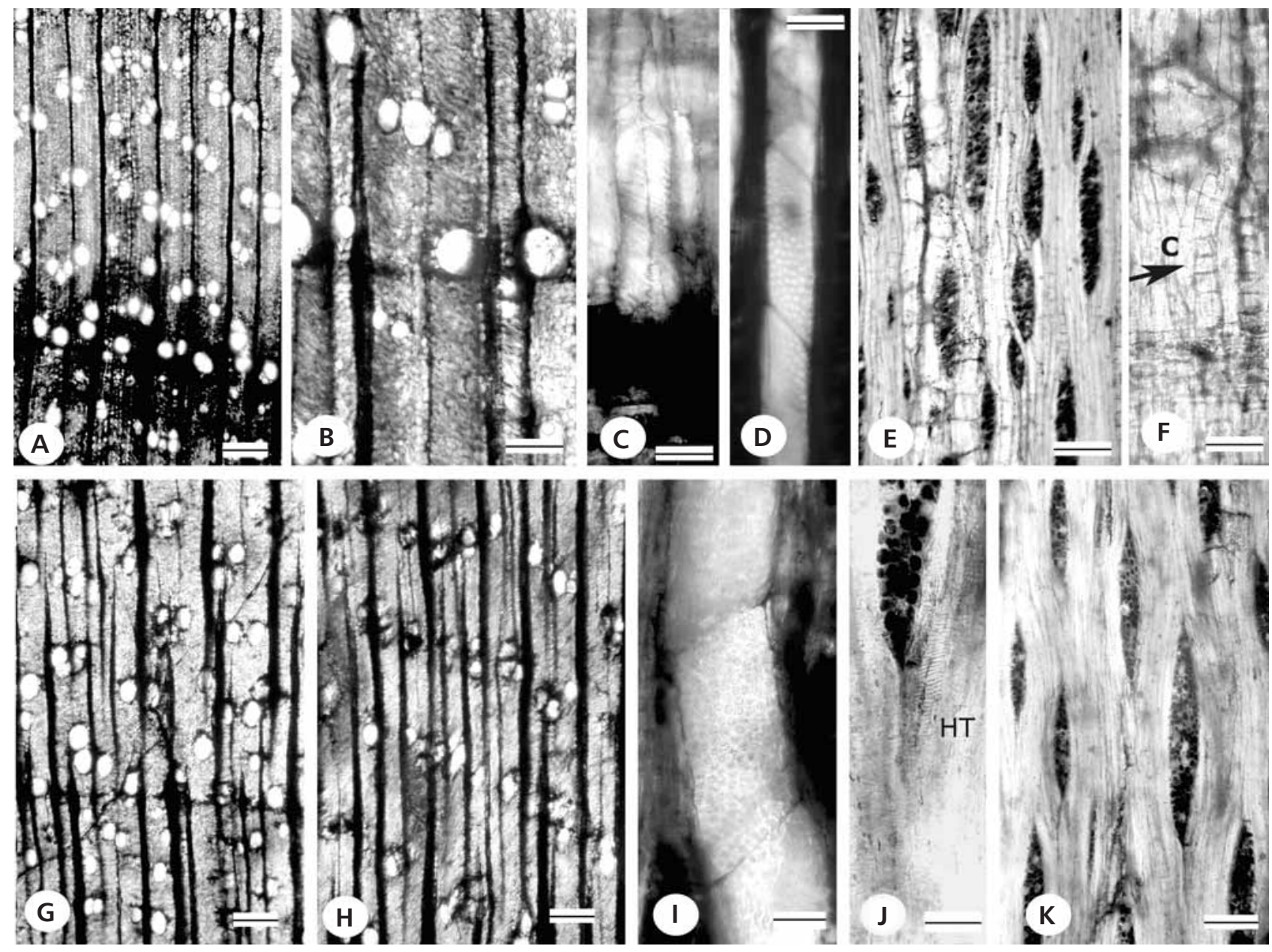

Figure 5. Wood anatomy of Eocene Ulmus. A-F - Ulmus danielii. UF 24562. A - vessels in diagonal to tangential arrangement, widely spaced vessels in earlywood. B - detail of growth ring boundary. C - helical thickening in narrow vessel element. D - crowded alternate intervessel pitting. E - rays mostly 3-4 seriate, locally storied axial parenchyma. F-radial section, chambered axial parenchyma (arrow, C). $\bullet \mathrm{G}-\mathrm{K}-\mathrm{cf}$. Ulmus sp. UF 24563 . G - diffuse porous wood, vessels solitary and in radial multiples and small irregular groups, axial parenchyma paratracheal vasicentric and marginal. $\mathrm{H}-\mathrm{vessels}$ tending to diagonal to tangential arrangement. I - crowded alternate intervessel pitting, simple perforation plates. J - helical thickenings (HT) in narrow tracheary element. $\mathrm{K}-$ homocellular rays mostly $3-4$ seriate. TS $=$ transverse section. RLS = radial longitudinal section. TLS $=$ tangential longitudinal section. $\bullet$ Scale bars $=200 \mu \mathrm{m}$ in $\mathrm{A}, \mathrm{G}, \mathrm{H} ; 100 \mu \mathrm{m}$ in $\mathrm{B}, \mathrm{D}, \mathrm{E}, \mathrm{K} ; 50 \mu \mathrm{m}$ in $\mathrm{C}, \mathrm{F}, \mathrm{I}, \mathrm{J}$.

Etymology. - This species is named for Jim Wood, on whose land locality 279 is located.

Similarities to extant woods. - The combination of semiring porosity (to ring porosity), vessels in diagonal to tangential arrangement, medium to large intervessel pits, vessel-ray parenchyma pits that are not enlarged but have reduced borders, non-septate fibers, predominantly paratracheal parenchyma that is not aliform, at least some homocellular rays, and storied axial parenchyma, but rays not storied, occurs in the Ulmaceae, particularly the temperate genera Planera and Ulmus.

The occurrence of mostly homocellular rays and crystals in chambered axial parenchyma, rather than in ray parenchyma, supports the identification of the fossil as Ulmus.
The combination of thick-walled fibers, small-medium earlywood vessel diameters, and lack of a pronounced difference between earlywood and latewood vessel diameter are features seen in Section Trichoptelea, Subgenus Oreoptelea. However, the crystalliferous strands of the Post wood are longer than those of Section Trichoptelea, and are not inflated. The earlywood zone of Ulmus woodii wood is more continuous than that typical of Section Trichoptelea.

Comparisons with other fossil woods. - Fossil woods of Ulmus occur in the Miocene Vantage Fossil Forests, Washington (Prakash \& Barghoorn 1961a, b); they differ from Eocene elms as they are distinctly ring porous. The Vantage Ulmus miocenica and $U$. pacifica have characteristics of Subgenus Oreoptelea, whereas U. baileyana has charac- 
teristics of Subgenus Ulmus (Wheeler \& Dillhoff, in preparation).

Late Tertiary European and Japanese woods assigned to Ulmus or Ulmoxylon also are distinctly ring porous (e.g., Burgh 1978, Watari 1952).

\section{Ulmus danielii Wheeler \& Manchester, 2002}

Figure 5A-F

Description. - Growth rings distinct.

Semi-ring porous to diffuse porous. Earlywood vessels mostly solitary, rounded in outline, and in radial multiples of $2-3$, vessels not in a continuous line. Latewood vessels in radial multiples and clusters in diagonal to wavy tangential bands. Mean tangential diameter of earlywood vessels 87 (11), range 63-136 $\mu \mathrm{m}$. Intervessel pits crowded alternate, angular in outline, $c a 10 \mu \mathrm{m}$ across, narrow vessels with spiral thickenings. Thin-walled tyloses.

Axial parenchyma paratracheal, intermixed with vessels and vascular tracheids, and marginal.

Fibers thick-walled, without obvious pits.

Rays 1-6-seriate, mostly 3-5. Homocellular, composed of procumbent cells. Total multiseriate ray height averages 259 (98), range $120-450 \mu \mathrm{m}$.

Solitary prismatic crystals in chambered axial parenchyma strands common, up to 20 chambers.

Material. - UF 24562, diameter about $10 \mathrm{~cm}$.

Comments. - This wood is similar to Ulmus danielii from the middle Eocene Clarno Nut Beds (Wheeler \& Manchester 2002), and is assigned to the same species. Ulmus danielii is distinguished from $U$. woodii by more variable spacing of the earlywood pores and consistently shorter rays.

\section{cf. Ulmus}

Figure 5G-K

Description. - Diffuse porous, with vessels solitary, in radial multiples and small groups of vessels, which tend to a diagonal to angential arrangement. Mean tangential diameter 96 (12) $\mu \mathrm{m}$. Perforation plates simple, intervessel pitting crowded alternate, with included apertures. Narrow tracheary elements with helical thickenings. Mean vessel element length 207 (64) $\mu \mathrm{m}$, range 100-400 $\mu \mathrm{m}$.

Axial parenchyma paratracheal and marginal.

Fibers thick-walled without obvious pits.

Rays mostly 3-4 seriate. Homocellular, composed of procumbent cells. Total multiseriate ray height 267 (89) $\mu \mathrm{m}$, range $100-465 \mu \mathrm{m}$.

Material. - UF 24563, diameter about $10 \mathrm{~cm}$.
Comments. - The combination of diagonally to tangentially arranged vessels, helical thickenings in narrow vessel elements, vasicentric and marginal axial parenchyma, and homocellular rays that are mostly 4-seriate is consistent with the Ulmaceae. The cross-sectional appearance of this wood is similar to that of the diffuse porous species Ulmus lanceifolia. However, U. lanceifolia commonly has chambered crystalliferous axial parenchyma and the fossil does not. We hestitate to assign this wood a specific epithet because the vessel-ray parenchyma pit type is not known.

\section{General conclusions}

Within Ulmaceae, all extant genera have distinctive anatomy. Within present-day Ulmus, most species of Subgenus Ulmus overlap in earlywood characteristics (depth of earlywood zone and tangential diameter) and ray sizes, and hence are difficult to distinguish from one another. Ulmus rubra and $U$. pumila are similar in having a broad earlywood zone. In Subgenus Oreoptelea, Section Blepharocarpus and Section Trichoptelea are distinct from one another, the former having wide (often > $200 \mu \mathrm{m}$ ) earlywood vessels and thin-walled fibers, the latter with narrower (usually $<150 \mu \mathrm{m}$ ) earlywood vessels, thick-walled fibers and crystals usually in enlarged cells. Section Lanceifolia, which has not been assigned to a subgenus, is diffuse porous. Two of the three Eocene woods described herein are most similar to Section Trichoptelea. However, assigning fossil woods to extant groups of species is compromised by the likelihood of Eocene woods having different porosity than their closest living relatives, e.g., being diffuse or semi-ring-porous rather than ring porous.

To the best of our knowledge, it is a general phenomenon that trees that produce ring porous woods are deciduous (Zimmermann 1983). How well defined the earlywood zone is and how distinct it is from the latewood zone varies within some species, and can be affected by water availability. Page (1993) looked at multiple samples of Robinia pseudoacacia (Leguminosae). Some samples came from well-watered trees grown in parks in California. These samples did not have as distinct an earlywood zone as did samples from Robinia in its native range. Samples of Ulmus procera (Hw 33262, Hw 33263) grown at the Arnold Arboretum had wider earlywood zones than did samples from the species' native Europe. Given that porosity in Ulmus and other genera can be affected by environment it is not surprising that Ulmaceae growing in the warmer, and more equable climates of the Eocene did not have as distinctive earlywood zones as seen in extant Ulmus.

Also, Denk \& Dillhoff (2005) found characteristics in Eocene Ulmus twigs bearing both young leaves and flowers that indicated a different timing in the appearance of leaves and flowers than occur today, which indicates 
differences in physiology and timing of auxin production. Extant ring and diffuse porous species have different sensitivities to auxin (Zimmermann 1983); the physiology associated with distinct ring porosity appears to have not yet evolved in Eocene Ulmaceae. Evidence for this includes the semi-ring porous wood known as Zelkovoxylon from the early Eocene of Yellowstone National Park, Wyoming (Wheeler et al. 1978) and late Eocene of Florissant Fossil Beds National Monument, Colorado (Wheeler 2001). Woods assigned to this genus have crystals in enlarged ray parenchyma cells as in present-day Zelkova, but present-day Zelkova woods are distinctly ring-porous. Whether the North American Zelkovoxylon woods are associated with the extinct genus Cedrelospermum or associated with plants that had foliage and fruits similar to Zelkova is unknown.

The overview of extant Ulmaceae wood presented here can provide context for a critical review of the fossil record of the Ulmaceae and helping reconstruct the family's history. It also shows the need for future phylogenetic analyses to examine additional species so as to resolve the subgeneric affinities of the east Asian species that have distinctive wood anatomy (e.g., Ulmus uyematsuii and $U$. castaneifolia).

\section{Acknowledgments}

We are grateful to Jim Wood for giving permission to collect on his ranch where locality UF 279 is located, and Shuichi Noshiro, FFPRI, Tsukuba, Japan, who shared information and images of Asian Ulmus. We thank Jakub Sakala for the invitation to participate in the fossil wood symposium at $7^{\text {th }}$ European Paleobotany-Palynology Conference; this paper is based on a presentation at that meeting. This work was partially supported by NSF Grants BRC 0237368 and DBI / BDI 0518386 (EW).

\section{References}

BRAZIER, J.D. \& FRANKLIN, G.L. 1961. Identification of hardwoods. A microscope key. Forest Products Research Bulletin 46, 1-96.

BURGH, J. VAN DER 1978. Hölzer aus dem Pliözan der Niederheinischen Bucht. Fortschritte in der Geologie von Rheinland und Westfalen 28, 213-275.

DENK, T. \& DillhofF, R.M. 2005. Ulmus leaves and fruits from the Early-Middle Eocene of northwestern North America: systematics and implications for character evolution within Ulmaceae. Canadian Journal of Botany 83, 1663-1681.

DÉTIENNE, P. \& JACQUET, P. 1983. Atlas d'identification des bois de l'Amazonie et des régions voisines. $640 \mathrm{pp}$. Centre Technique Forestier Tropical, Nogent s/Marne.

FAHN, A., WERKER, E. \& BAAS, P. 1986. Wood anatomy and identification of trees and shrubs from Israel and adjacent regions. 221 pp. Israel Academy of Sciences and Humanities.

FFPRI WOOD IDENTIFICATION DATABASE TEAM 2002 onwards. Microsoopic identification of Japanese woods. http://f030091.ffpri. affrc.go.jp/index-E3.html.
Flora EUROPAEA EDITORIAL COMMITTEE. Flora Europaea. On-line digital version, housed by Royal Botanic Gardens Edinburgh. URL: http://rbg-web2.rbge.org.uk/FE/fe.html\#form.

GRÖSSER, D. 1977. Die Hölzer Mitteleuropas. Ein mikrophotographischer Lehratlas. 208 pp. Springer-Verlag, Berlin.

GRUDZINSKAYA, I.A. 1967. Ulmaceae and reasons for distinguishing Celtidoideae as a separate family Celtidaceae Link. Botanicheskii Zhurnal 52, 1723-1749 (in Russian).

ITOH, T. 1995. Anatomical description of Japanese hardwoods I. Wood Research and Technical Notes 31, 81-181 (in Japanese).

KRIBS, D.A. 1968. Commercial foreign woods on the American market. 241 pp. Dover Publications, New York.

KUNG-CHI, Y.\& YU-SHIU HUANG, Y. 1987. Minute structure of Taiwanese woods. 172 pp. Hua Shiang Yuan Publishing Col, Taipei, Taiwan.

LEBACQ, L. 1955. Atlas anatomique des bois du Congo Belge. Vol. I. Publicatons de L'Institut National Pour L'Etude Agronomique du Congo Belge, Bruxelles.

Liguo, F., Yiqun, X. \& Whittemore, A. 2003. Ulmaceae. Flora of China 5,1-19. http://www.efloras.org/florataxon.aspx?flora_id=2\&taxon_id=10928.

MANCHESTER, S.R. 1989a. Extinct ulmaceous fruts from the Tertary of Europe and western North America. Review of Palaeobotany and Palynology 52, 119-129.

MANCHESTER, S.R. 1989b. Systematics and fossil history of Ulmaceae, 221-251. In CRANE, P.R. \& BLACKMORE, S. (eds) Evolution, Systematics, and Fossil History of Hamamelidae. Vol. 2. Clarendon Press, Oxford, UK.

MANCHESTER, S.R. \& TIFFNEY, B.H. 2001. Integration of paleobotanical and neobotanical data in the assessment of phytogeographic history of Holarctic angiosperm clades. International Journal of Plant Science 162 (6 Suppl.), S19-S27.

MetCalfe, C.R. \& CHALK, L. 1950. Anatomy of the dicotyledons. Volumes I, II. 1500 pp. Oxford, Clarendon Press.

MinaKI, M., NoshIRO, S. \& SUZUKI, M. 1988. Hemiptelea mikii sp. nov. (Ulmaceae), fossil fruits and woods from the Pleistocene of central Japan. Botanical Magazine, Tokyo 101, 337-351.

NORMAND, D. \& PAQUIS, J. 1976. Manuel d'identification des bois commerciaux. Tome 2. Afrique guineo-congolaise. 335 pp. Centre Technique Forestier Tropical, Nogent s/Marne.

PAGE, V.M. 1993. Anatomical variation in the wood of Robinia pseudoacacia L. and the identity of Miocene fossil woods from southwestern United States. International Association of Wood Anatomists Journal 14, 299-314.

PEARSON, R.S. \& BROWN, H.P. 1932. Commercial timbers of India. Their distribution, supplies, anatomical structure, physical and mechanical properties and uses. Volume II. $548 \mathrm{pp}$. Government of India, Central Publication Branch, Calcutta.

Pérez Olvera, C., DE PaZ, T., CARmona Valdovinos, F. \& los ANGELES Rogel GÓMEZ, M. 1980. Estudio anatomico de la Madera de 43 especies tropicales. Boletin Técnico Instituto Nacional de Investigaciones Forestales 63, 1-276.

PRAKASH, U. \& BARGHOORN, E.S. 1961a. Miocene fossil woods from the Columbia Basalts of Central Washington. Journal of the Arnold Arboretum 42, 165-203.

PRAKASH, U. \& BARGHOORN, E.S. 1961b. Miocene fossil woods from the Columbia Basalts of Central Washington. II. Journal of the Arnold Arboretum 42, 347-362.

RiCHTER, H.G. \& DALlwiTZ, M. J. 2000 onward. Commercial timbers: descriptions, illustrations, identification, and information retrieval. In English, French, German, and Spanish. Version: 16 ${ }^{\text {th }}$ April 2006. http://delta-intkey.com/wood/en/.

SAKALA, J. 2002. First record of fossil angiosperm wood (Ulmoxylon, Ulmaceae) from the famous locality of Bilina (Czech Republic, Early Miocene). Comptes Rendus Palévol 1, 161-166.

SCHOCH, W., Heller, I., SCHWEINGRUBER, F.H. \& KIENAST, F. 2004. Wood anatomy of central European species. www.woodanatomy.ch. 
Soltis, D., Soltis, P.S., EndRess, P.K. \& CHASE, M.W. 2005. Phylogeny and evolution of Angiosperms. 370 pp. Sinauer, Sunderland, Mass.

SteVEnS, P. F. 2001 onwards. Angiosperm Phylogeny Website. Version 7, May 2006 [and more or less continuously updated since]. http://www.mobot.org/MOBOT/research/APweb/.

SUZUKI, M. \& HIRAYA, C. 1989. Fossil wood flora from the pumice tuff of Yanagida Formation (Lower Miocene) at Mawaki, Noto Peninsula. Annals of Science of Kanazawa University 26, 47-75.

SCHWEINGRUBER, F.H. 1990. Microscopic Wood Anatomy; Structural variability of stems and twigs in recent and subfossil woods from Central Europe. $3^{\text {rd }}$ edition. Birmensdorf, Eidgenössische Forschungsanstalt WSL.

STERN, W.L. 1988. Index Xylariorum: Institutional wood collections of the world. $3^{\text {rd }}$ edition. International Association of Wood Anatomists Bulletin, New Series 9, 203-230.

SWEITZER, E.M. 1971. Comparative anatomy of Ulmaceae. Journal of the Arnold Arboretum 52, 523-585.

Sytsma, K.J., Morawetz, J., Perez, J.C., PePokroefF, M., Conti, E., ZJHRA, M., HALL, J.C., \& CHASE, M.W. 2002. Urticalean Rosids: circumscription, Rosid ancestry, and phylogenetics based on rbcL, trnL-F, and ndhF sequences. American Journal of Botany 89, 1531-1546.

TORTORELLI, L.A. 1956. Maderas y bosques argentinoas. 910 pp. Editorial Acme, Buenos Aires.

USDA, ARS, National Genetic Resources Program. Germplasm Resources Information Network - (GRIN) [Online Database]. National Germplasm Resources Laboratory, Beltsville, Maryland. http://www.ars-grin.gov/cgi-bin/npgs/html/tax_search.pl.

WATARI, S. 1952. Dicotyledonous woods from the Miocene along the Japan-Sea of Honsyu. Journal of the Faculty of Sciences, University of Tokyo, Section III (Botany) 6, 97-134.
WHEELER, E.A. 2001. Fossil dicotyledonous woods from the Florissant Fossil Beds National Monument, Colorado, 197-214. In EVANOFF, E., GREGORY-WODZICKI, K.M. \& JOHNSON, K.R. (eds) Stratigraphy and Fossil Flora of the Florissant Formation, Colorado. Proceedings Denver Museum of Science and Nature, Series 4(1).

WHEELER, E.A., BAAS, P. \& GASSON, P. (eds) 1989. IAWA list of microscopic features for hardwood identification. International Association of Wood Anatomists Bulletin, New Series 10, 219-332.

WHEELER, E.A., LAPASHA, C.A. \& MiLLER, R.B. 1989. Wood anatomy of elm (Ulmus) and hackberry (Celtis) species native to the United States. International Association of Wood Anatomists Bulletin, New Series 10, 5-26.

WheEler, E.A. \& MANCHESTER, S.R. 2002. Woods of the Middle Eocene Nut Beds Flora, Clarno Formation, Oregon, USA. 188 pp. IAWA Journal Supplement 3.

WheEler, E.A., MANCHESTER, S.R., \& WiEMAnN, M. 2006. Eocene woods of central Oregon. PaleoBios 26(3), 1-6.

WHEELER, E.A, SCOTT, R.A. \& BARGHOORN, E.S. 1978. Fossil dicotyledonous woods from Yellowstone National Park. II. Journal of the Arnold Arboretum 59, 1-28.

WIEGREFE, S.J., SYTSMA, K.J. \& GURIES, R.P. 1994. Phylogeny of elms (Ulmus, Ulmaceae): Molecular evidence for a sectional classification. Systematic Botany 19, 590-612.

WIEGREFE, S.J., SYTSMA, K.J. \& GURIES, R.P. 1998. The Ulmaceae, one family or two? Evidence from chloroplast DNA restriction site mapping. Plant Systematics and Evolution 210(3-4), 249-270.

ZHONG, Y., BAAS, P. \& WHEELER, E.A. 1992. Wood anatomy of trees and shrubs from China. IV. Ulmaceae. International Association of Wood Anatomists Bulletin, New Series 13, 419-453.

ZIMMERMANN, M.H. 1983. Xylem structure and the ascent of sap. 143 pp. Springer, New York.

\section{Appendix - Samples examined and literature sources for tables I, II}

Ampelocera: A. edentula FPAw 10839, Uw 227, Détienne \& Jacquet 1983; A. hottlei Uw 34855, INIFw 432, Pérez Olvera et al. 1980.

Hemiptelea davidii: Hw 5283, Minaki et al. 1988.

Holoptelea: H. grandis SJRw 23262, Lebacq 1955, Normand \& Paquis 1976; H. integrifolia FPAw I.24, Pearson \& Brown 1932.

Phyllostylon rhamnoides: SJRw 782, SJRw 23409, INIF 432. Uw 25780, Kribs 1968, Richter \& Dallwitz 2000 onwards, Tortorelli 1956.

Planera aquatica: SJRw 6699, SJRw 1116.

Ulmus: U. alata (15 samples): $\mathrm{BWCw} 8218, \mathrm{BWCW} 8369$, BWCw 8365, PACw 3408, PACw 6282, PACw 6283, MADw 2121, MADw 2122, MADw 2126, MADw 2128, MADw 10069 , MADw 10071, MADw 19446 [for more detail see Wheeler et al. 1989]; U. americana (10 samples) BWCw 8014, BWCw 8019, BWCw 8429, BWCw 8595, PACw 6272, PACw 6274, PACw 6275, PACw 6276, PACw 6277, Tw 52973 (photo) [for more detail see Wheeler et al. 1989]; U. canescens Fahn et al. 1986, U. castaneifolia (U. multinervis) CAFw 15928, CAFw 20280, Zhong et al. 1992; U. changii HEFw 002179; U. crassifolia (15) BWCw 8559, BWCw 8560, BWCw 8680, Hw 29887, PACw 3409, PACw 6264, PACw 6265, MADw 8474, MADw 8475, MADw 10065, MADw 10066, MADw 35965, SJRw 11927 [for more detail see Wheeler et al. 1989]; U. davidiana CAFw 7767, HEFw 82c844; U. davidiana var. japonica TWTw 18443, TWTw 18861 (FFPRI site), TI 4774 and USGSw 529 (label U. japonica); U. glabra FPAw gb.39, SJRw 19686; U. laciniata TWTw 18696, TWTw 18497 (FFPRI site); U. lanceifolia CAFw 6813, HEFw 146600, Pearson \& Brown 1932; U. macrocarpa CAFw 5321; $U$. mexicana USw 15582, PACw 8180; $U$. minor FHOw 8 (label $U$. campestris), FHOw 2498 (label $U$. carpinifolia), SJRw 9687; $U$. parvifolia TWTw 19622, TWTw 19626 (FFPRI site); U. pumila (4) CAFw 13822, HEFw 002134, Hw 9081, Hw 20393; U. procera (3) Hw 33262, Hw 33263, UN 92 (photos); U. rubra (10) BWCw 8015, BWCw 8167, BWCw 8482, PACw 6266, PACw 6267, PACw 6268, PACw 6269, PACw 6270, PACw 6271, Tw 14440 (photos); U. serotina (5) BWCw 8474, Hw 20651, Hw 33267, MADw 19329, MADw 11028; U. thomasii (15) BWCw 8016, BWCw 8024, BWCw 8153, BWCw 8481, BWCw 8635, PACw 3411, PACw 6279, PACw 6280, MADw 2123, MADw 2124, MADw 2127, MADw 6492, MADw 7228, MADw 7229, MADw 7230, Uw 31164 (photo); U. uyematsui CAFw 5033; U. wallichiana, see Pearson \& Brown 1932.

Zelkova: Z. serrata FPAw j.14, TWTw 14915, TWTw 18610, TWTw 18862, PACw 7213, CAFw 7340, Itoh 1995, Kribs 1968, Kung-Chi \& Yu-Shiu Huang 1987. 